Asian Journal of Managerial Science ISSN: 2249-6300 Vol.7 No.2, 2018, pp.1-6 (C)The Research Publication, www.trp.org.in

\title{
Impact of Capital Structure on Profitability:An empirical analysis of listed firms in India
}

\author{
Atif Ghayas ${ }^{1}$ and Javaid Akhter ${ }^{2}$ \\ ${ }^{1}$ Research Scholar, ${ }^{2}$ Professor, Department of Business Administration, \\ Aligarh Muslim University, Aligarh, Uttar Pradesh, India \\ E-Mail: atifghayas91@gmail.com
}

\begin{abstract}
This study aims to empirically examine and analyze the impact of capital structure decision on the firm's profitability by using a sample of 35 Indian pharmaceutical companies listed on Bombay Stock Exchange (BSE) during the period of 5 years from 2012 to 2016. Regression Analysis is used to measure the extent and nature of the relationship. Capital structure variables used in the study are ratio of longterm debt to total assets (LDA), ratio of short-term debt to total assets (SDA) and ratio of Total debt to total assets (DA) while profitability has been measure by Return on Equity (ROE). Firms Size (SIZE)and Salesgrowth(GROW) are also used as control variables. Results reveal a positive effect of SDA and DA on ROE, while a weak-to-no effect was found of LDA on ROE.
\end{abstract}

Keywords: Capital structure, Profitability, Leverage, Pharmaceutical, India

\section{INTRODUCTION}

Financing decision is one the most important decision of every firm as it has its direct implication on the profitability of the firm. Every firm seeks to design a perfect capital structure with an ideal ratio of debt and equity source of finance, which can minimize the overall cost of financing while maximizing the value of the firm. The issue of capital structure and its relationship with firm value gained attention with Modigliani and Miller's irrelevant proposition (1958). It proposed that capital structure choice has no effect on value of the firm under certain assumptions. These assumptions were:absence of corporate taxes, free access of market information to investors and no transaction cost.

However, as these assumptions don't hold in real world, MM revised their proposition and included corporate taxed in the original proposition. Thus, they suggested that value of the firm will increase with increase debt financing as interest income is taxes deductible. Later on, several researchers found many other variables which affect capital structure decisions as well as financial performance such as fixed assets, liquidity, size, firm age, growth etc. This study attempts of find the nature of effect of capital structure choice on the profitably of the firms in Indian pharmaceutical companies listed on Bombay Stock Exchange. As it is evident from the previous studies that firm size and firm growth also influence the profitability of the firms, these factors are also considered as control variables while predicting the relationship between capital structure and profitability.

\section{LITERATURE REVIEW}

\section{A. Theoretical Literature}

MM Theorem:Modigliani and Miller in their seminal work'MM irrelevance proposition (1958)'asserted that the value of the firm is independent of its capital structure decision. The theorem proposes that firm has a set of expected cash flows, capital structure decision only affects how these cash flows are divided among the debt and equity investors. The theorem is based on certain assumptions of perfect capital market, absence of taxes, rational Investors, homogeneous expectations and equivalent risk classes. There are two propositions, first is based on the arbitrage process which says that investors can use home-made leverage for corporate leverage which results in independence of firm value from its leverage. Hirshleifer (1966) and Stiglitz (1969) are additional contributors to this theorem. Second proposition suggests that dividend policy of a firm does not affect its current share price as well as total shareholder returns. (Miller and Modigliani, 1961). Hence, neither capital structure nor dividend policy decisions matter in perfect market conditions.

Later on, many researchers tried to relax some of the assumptions considered in MM hypothesis like Taxes, transactions cost, agency issues, bankruptcy cost, lack of information symmetry between stakeholders, time-varying financial market opportunities, etc. As a result, many different theories have been proposed.

Trade-off Theory: 'Trade-off' refers to the theory which proposes that firms balance between various costs and benefits of using debt to create an optimum capital structure. There are three factors which influences capital structure decision. Firstly, interest payments reduces the taxesof the firm as it is a tax deductible expense and increases cash flows after tax. Secondly, due to the Agency Costs. According to Jensen \& Meckling (1976), "It is the costs of monitoring the managers so that they act in the interests of the shareholders”. Thirdly, Bankruptcy Costs, which occurs due to the possibility of default on debts. The bankruptcy cost increases with the level of debt after the optimal point.Dynamic trade off theory takes into 
accountthe time element. This theory leads to accurate financial decisions as it also considers financial margins and future possibilities. For e.g.any firm may expect to pay funds and other may need to raise funds. The funds can be acquired through debt source or through equity source or a combination of both. Firms keeps high levels of debt to benefit from the tax savings as they as they spend costlessly to adjust to the shocks. Goldstein et al. (2001) analyzed that low leverage firms today have an option to increase its leverage tomorrow. Strebulaev (2007) and Fischer et al. (1989) proposed similar models.

Pecking Order Theory:According to this theory, firms exhibit a particular preference of internal sources over external sources while fulfilling their capital requirement needs. In case of additional capital needs, Firms first utilize their retained earnings, then debt financing and ultimately equity sources. This is based on two factors, financing cost of capital as well as information dissemination about the firm. Internal sources of funds doesn't have any financial cost associated with them as in case of debt and equity financing, which makes internal sources prime choice of the firms. Moreover, external financing like debt and equity issue entails some critical information about the firm's health which may alter the perceived value of the firm's assets in the mind of potential investors. Thus, managers try to minimize the involuntary flow of negative information to investors by choosing internal source over external sources as demonstrated by the model of Myers and Majluf (1984). According to Frank and Goyal (2007), Agency cost is also an important factor in pecking order theory. Transaction costs of debt is less than equity resulting in debt preference. Managers don't want to dissolve their control over the firm, thus avoiding equity issue. Holmes and Kent (1991), Hamilton and Fox (1998).

Market Timing Theory:According to this theory, market fluctuations affect capital structure of the firms. Firm tries to time its equity issues when the market is overpriced and avoid when market is underpriced. Thus, in later case, firms prefer other sources of finance such as retained earnings and debt. There are two approaches, First considers market agent to be rational which averts the information asymmetry problem and other considers agents to be irrational, due to which stocks are considered mispriced. (Baker and Wurgler, 2002).

\section{B. Empirical literature}

Many studies have been done around the world to test the above theories of capital structure. Abor J. (2005) examined the nature of the association between capital structure and profitability of listed firms in Ghana. With the help of panel-data methodology, found a positive association between Short term leverageand total leverage with profitability. While an inverse relationship was found between long term leverage and profitability. Abu-Tapanjeh A.M., (2006) studied factors such as firm size, age, debt ratio and ownership structure to study the above
relationship.Findings revealed that firm structure is a major factor which influences profitability.

Zeitun, R. and Tian, G. G., (2007) used panel data to examine the impact of capital structure on corporate performance in Jordan and found that a capital structure has a strong negative influence on the firm's accounting as well market performance measures. Ibrahim El-Sayed Ebaid, (2009) studied Egyptian firms to assess the influence of capital structure decision on performance. Using ROE, ROA, GPM, results indicated a weak impact of Capital structure choice on profitably. Nimalathasan B., Brabete V. (2010)selected Sri Lankan firms to study the interrelationship and found that $\mathrm{D} / \mathrm{E}$ ratio is positively and strongly associated to all profitability ratios GPR, OPR and NPR except ROCE and ROI. D/A ratio is has a positive relationship with OPR, NPR and ROCE. Also CG ratio is also positively related to GPR and NPR.

Azhagaiah R., Gavoury C., (2011) used a sample of 102 IT firmscategorized into three categories on the basis of two attributes firm revenue and firm size. Theyfound a strong inverse association between capital structure and Profitability. Gill A, Biger N, Mathur N, (2011) reexamined the Abor's (2005) resultsof 272 American service and manufacturing firms listed on New York Stock Exchange and found a positive relationship between STD to TA, LTD to TA and TDto TA and profitability. Shubita M.F., Alsawalhah J.M., (2012)also reexamined Abor's (2005) findings on Amman Stock Exchange. The results indicated aninverse relation between debt and profitability. Chisti K.A., Ali K. \& Sangmi M., (2013) studied automobile industry in India and found that $\mathrm{D} / \mathrm{E}$ ratio is inversely related to profitability ratios. $\mathrm{D} / \mathrm{A}$ ratio and Interest coverage ratio are positively related to profitability ratio. $\mathrm{D} / \mathrm{A}$ ratio and Interest Coverage ratios are negatively related with $\mathrm{D} / \mathrm{E}$ ratio, butD/A ratio is positively related with Interest Coverage ratio.Zadeh R.A., Nemati F., Babaei B., Narimani,S., (2014) studiedThe relationship between Profitability and Sustainability of the Capital Structure of firms on Tehran Stock Exchange. Findings revealed a direct association between company's growth opportunities and the ratio of changes in debt. Additionally,an inverse relationship was found between profitability index and the ratio of changes in debt of companies.

\section{C.Research Gap}

The existing literature primarily consists of studies regarding relationship between financial leverage, firm's size and fixed assets. Literature regarding the nature of impact of financial leverage on profitability is scarce. Moreover, how the factors like firm size and growth influences this relationship is also not known very well. Additionally, most of the studies are related to the developed economies and researches in emerging economies like Indian are very few. Thus, there is an eminent need to shed some light on this relationship in Indian context. This study seeks to study the effect of capital structure on the profitability of Indian 
Pharmaceutical firms listed on the Bombay Stock Exchange (BSE).

\section{D.Objectives of the study}

1. To study the capital structure of selected trading companies of India.

2. To examine the nature of relationship between capital structure and profitability of Indian Pharmaceutical companies.

3. To study the effect of factors like firm Size and Sales Growth on the relationship between capital structure and profitability

\section{E.Hypothesis of the study}

1. There is no significant impact of ratio of Short-Term Debt to Total Assets (SDA) on Return on Equity (ROE).

2. There is no significant impact of ratio of (SDA) LongTerm Debt to Total Assets on Return on Equity (ROE).

3. There is no significant impact of ratio of (DA) Total Debt to Total Assets on Return on Equity (ROE).

\section{METHODOLOGY}

\section{A.Data}

This study uses data of all the pharmaceutical firms that have been listed on the S\&P BSE 500 index over a five-year period from the year 2012 to 2016. Thus a sample of 35 firms was chosen to be included in the analysis.

\section{B.Variables}

The study uses most popular proxy for Accounting based profitability measure used in the previous studies i.e. Return on Equity(ROE), calculated by dividing earnings before interest and taxes (EBIT) to total equity. Similarly, variables which are used in the previous studies for measuring leverage are used. These are Short-term Debt to the Total Capital (SDA), Long-term Debt to Total Capital (LDA); and Total Debt to Total Capital. (DA). Previous studies suggests that factors such as Firm Size (SIZE) and Sales Growth (GROW)also influence the relationship between capital structure and profitability, hence these factors are included in the model as control variables.

\section{C.Method of data analysis}

The sample collected for the study is panel in nature i.e. cross-sectional data has been collected over several time periods. OLS Regression analysis technique is used to test the relationship between capital structure ration and profitability variables. Below figure (Fig. 1) shows the conceptual model used in the study.

\section{Regression Model}

The relationship between capital structure and profitability is estimated in the following regression models:

$$
\begin{aligned}
& \mathrm{ROE}=\beta_{0}+\beta_{1} \mathrm{SDA}+\beta_{2} \mathrm{SIZE}+\beta_{3} \mathrm{GROW}+e \\
& \mathrm{ROE}=\beta_{0}+\beta_{1} \mathrm{LDA}+\beta_{2} \mathrm{SIZE}+\beta_{3} \mathrm{GROW}+e \\
& \mathrm{ROE}=\beta_{0}+\beta_{1} \mathrm{DA}+\beta_{2} \mathrm{SIZE}+\beta_{3} \mathrm{GROW}+e
\end{aligned}
$$

Where:

ROE:Return on Equity

SDA:Short-term debt divided by the total Assets

LDA: Long-term debt divided by the total Assets

DA: Total debt divided by the total Assets

SIZE: Log of Total Assets

GROW:Sales Growth

$e$ :Error term.

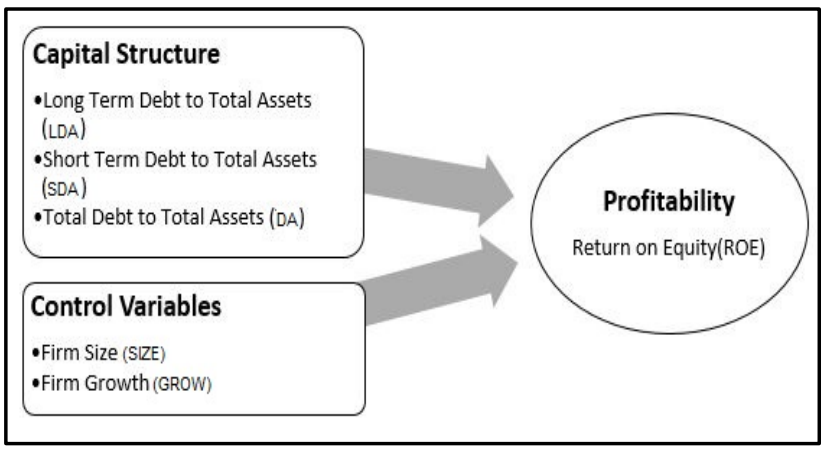

Fig. 1 Conceptual model of the Study

\section{ANALYSIS AND RESULTS}

\section{A.Descriptive Statistics}

Summary of the descriptive statistics of all the dependent and in depended variables used in the study are presented in the Table 1 . Mean value of ROE suggest that average ROE in the sample Pharmaceutical firms is $18 \%$, which can be considered as satisfactory performance.The average value of SDA is 0.312indicating that short-term debts comprises of nearly31\%of total enterprise value of the firms. On the other hand, theaverage value of long-term debt to total assets (LDA) is 0.149 , suggests that long-term debts finances around $15 \%$ of the totalassets of the firms.The variable Total Debt to total Assets (DA) suggests that nearly46\% of total assets are financed through debt capital. The results indicates that the sample firms used for the study are highly leveraged at $46 \%$ with majority of leverage is composed of short-term leverage which stands at $31 \%$.

\section{B. Regression Results}

The results of the regression models 1,2 , and 3 testing the relationship between capital structure and firm's performance are presented in the table 2, 3 and 4 respectively. Ordinary Least Square regression technique was used to examine the target relationship between capital structure and profitability variables. Regression technique was applied after fulfilling all the assumptions of regression analysis. Hausman test have been applied to each of the model to choose between fixed effect and random effect model. The results from the regression models (1), (2), and (3) suggests that the selected independent variables explains 
about 42, 2.2 and 23 percent influence on the dependent variable respectively. All the coefficients are statistically

significant at the confidence level of 95 percent.

TABLE I DESCRIPTIVE STATISTICS

\begin{tabular}{|c|c|c|c|c|c|c|}
\hline & ROE & SDA & LDA & DA & SIZE & GROW \\
\hline Mean & 18.65783 & 0.312193 & 0.149514 & 0.461707 & 4.356233 & 0.184635 \\
\hline Median & 17.11000 & 0.272070 & 0.125089 & 0.448656 & 4.354287 & 0.146088 \\
\hline Maximum & 215.3900 & 1.660594 & 0.542935 & 1.775172 & 5.590742 & 2.012772 \\
\hline Minimum & -234.0600 & 0.101622 & 0.001165 & 0.148092 & 3.011444 & -0.503428 \\
\hline Std. Dev. & 32.24820 & 0.180908 & 0.117067 & 0.207576 & 0.552693 & 0.286816 \\
\hline
\end{tabular}

In the following tables, table II shows result of model 1, whichexamines the impact of Short-term debt to Total Asset ratio (SDA) on ROE. Table IIIshows the results of model 2, which examines the impact of Long-term debt to Total Asset ratio (LDA) on ROE.Table IV shows the results of model 3, which examines the impact of Total debt to Total Asset ratio (DA) on the performance variable ROE. SIZE and GROW are used in each of the equations as control variables.

Regression result of the model 1 presented in the table II, which examines the impact of Short-term debt to Total Asset ratio (SDA) on ROE reports a significant positive relationship between the variable SDA and ROE at the confidence level of 95 percent. This indicates that any change in Short term debt in the firm's capital structure has a direct impact on the firm's profitability. However, the control variable SIZE and GROW doesn't have any significant impact on the dependent variable ROE. The result is consistence with the previous studies examining the debt level and profitability relationship e.g. Abor, (2005) and Gill, et al., (2011). The result underlines the fact that short-term debt is less expensive, and thus increasing the usage of short-term debt carrying low interest rate will result in increase in firm's profits.

TABLE II REGRESSION RESULTS OF MODEL 1

\begin{tabular}{|c|c|c|c|c|}
\hline Variable & Coefficient & Std. Error & t-Statistic & Prob. \\
\hline C & -22.24680 & 27.59756 & -0.806115 & 0.4213 \\
\hline SDA & 41.45299 & 15.23692 & 2.720563 & 0.0072 \\
\hline SIZE & 6.180885 & 5.792587 & 1.067034 & 0.2875 \\
\hline GROW & 5.621521 & 8.218063 & 0.684045 & 0.4949 \\
\hline
\end{tabular}

Table III presents the results of the regressionmodel 2 which examines the impact of Long-term debt to Total Asset ratio (LDA) on ROE shows that there is no significant relationships between Long term debt and Profitability. However, the coefficient of LDA is negative which suggests that Long-term debt and profits has inverse relationship.
This could be due to the fact that Long term debt carry high interest and its high usage may decrease the profitability. The results support earlier findings by Fama and French (1998), Graham (2000) and Booth et al., (2001). Insignificant relationship is also found between SIZE and GROW variables and ROE.

TABLE III REGRESSION RESULTS OF MODEL 2

\begin{tabular}{|c|c|c|c|c|}
\hline Variable & Coefficient & Std. Error & t-Statistic & Prob. \\
\hline C & 15.37010 & 23.68094 & 0.649049 & 0.5172 \\
\hline LDA & -10.94590 & 24.50541 & -0.446673 & 0.6557 \\
\hline SIZE & 0.991716 & 5.519430 & 0.179677 & 0.8576 \\
\hline GROW & 3.272155 & 8.439221 & 0.387732 & 0.6987 \\
\hline
\end{tabular}

The results presented in the Table IVof the model 3 which examines the impact of Total debt to Total Asset ratio (DA) on ROE shows that there exists a significant positive relationship between Total Debt and profitability. This suggest that increase in the debt level in the firm's capital structure leads to the increase in the profit levels of the firm i.e. the higher the debt, the higher the profitability. This finding is consistent withthe prior studies like Abor, (2005). Gill, et al., (2011),Nirajini. A, Priya, K.B., (2013). 
TABLE IV REGRESSION RESULTS OF MODEL 3

\begin{tabular}{|c|c|c|c|c|}
\hline Variable & Coefficient & Std. Error & t-Statistic & Prob. \\
\hline C & -5.985676 & 26.19344 & -0.228518 & 0.8195 \\
\hline DA & 25.66375 & 12.94581 & 1.982399 & 0.0490 \\
\hline SIZE & 2.697788 & 5.509717 & 0.489642 & 0.6250 \\
\hline GROW & 5.644515 & 8.375732 & 0.673913 & 0.5013 \\
\hline
\end{tabular}

From the above results, it can be summarized that debt has a significant influence on the profitability of the Indian Pharmaceutical firms. Increase in the debt usage, especially the short-term debt leads to an increase in the firm's profitability. This means that profitable firms depends more on debt financing compared to equity and is consistent with the precious studies like Hadlock and James (2002), Petersen and Rajan (1994) and Roden and Lewellen (1995) that profitable firms use more debt. However, control variables used in the study, SIZE and GROW doesn't have any impact on the firm profitability.

\section{Hypothesis Testing}

TABLE V HYPOTHESIS TESTING

\begin{tabular}{|c|l|c|}
\hline S.No. & \multicolumn{1}{|c|}{ Hypothesis } & Result \\
\hline 1 & There is no significant impact of ratio of Short-Term Debt to Total Assets (SDA) on Return on Equity (ROE). & Rejected \\
\hline 2 & There is no significant impact of ratio of (LDA) Long-Term Debt to Total Assets on Return on Equity (ROE). & Accepted \\
\hline 3 & There is no significant impact of ratio of (DA) Total Debt to Total Assets on Return on Equity (ROE). & Rejected \\
\hline
\end{tabular}

\section{CONCLUSIONS}

Optimal capital structure is one of the major issues in the field of modern finance. Every firm strives to increase its profitability by minimizing its various costs. It is hypothesized by many researchers that debt, being a cheaper source of capital leads to reduction in overall cost of the capital and thus increase in the net profitability. However, results of the empirical studies undertaken all over the world are contradicting in nature. Some report a positive relationship between debt level and profitability, others reports negative relationship, while some studies report no relationship at all. This study attempted to study this relationship in Indian context using a sample of 35 pharmaceutical firms listed on BSE 500 index during 5 year period between the years 2012 and 2016.

The results revealed a positive association between Short term debt to Total Assets (SDA) and Return on Equity (ROE), indicating that profitable firms employs more short term debt in the capital structure as it carries lower interest. The sample reported nearly 31 percent of short term debt in the capital structure, more than double the long term debts which is nearly 15 percent. However, the results indicated a negative and weak relationship between Long term Debt to total assets(LTD) and Return on Equity (ROE). In the end, results presented a significant positive relationship between total debt to total Assets(TD) and profitability (ROE) pointing to the fact that profitable firms employs moredebt in their capital structure as debt is a cheaper source of finance.

\section{REFERENCES}

[1] Abor J. (2005). The Effect of Capital Structure on Profitability: an empirical analysis of listed firms in Ghana. The Journal of Risk finance. 6(5). Part 1, 438-445.

[2] Abu-Tapanjeh A.M. (2006). An Empirical Study of Firm Structure and Profitability Relationship: The Case of Jordan. Journal of Economic \& Administrative Sciences. 22(1). 41 -59.

[3] Azhagaiah R., Gavoury C., (2011). The Impact of Capital Structure on Profitability with Special Reference to IT Industry in India, Managing Global Transitions. 9(4). 371-392

[4] Baker, M., \& Wurgler, J. (2002). Market Timing and Capital Structure. The Journal of Finance. 57(1). 1-32.

[5] Brennan, M. J., \& Schwartz, E. S. (1984). Optimal financial policy and firm valuation. Journal of Finance. 39(3). 593-607.

[6] Chisti K.A., Ali K., \&Sangmi M. (2013). Impact of Capital Structure on Profitability of Listed Companies (Evidence from India), The USV Annals of Economics and Public Administration. 13(1). 17. 183-191.

[7] Fischer, E. O., Heinkel, R., \& Zechner, J. (1989). Dynamic Capital Structure Choice: Theory and Evidence. Journal of Finance. 44. 1940.

[8] Frank, M. Z., \& Goyal, V. K. (2007). Trade-Off and Pecking Order Theories of Debt. Handbook of Corporate Finance: Empirical Corporate Finance. 2, 1-82.

[9] Gill, A, Biger, N., \& Mathur, N. (2011). The Effect of Capital Structure on Profitability: Evidence from the United States, International Journal of Management. 28(4) Part 1. 3-15.

[10] Goldstein, R., Ju, N. \& Leland, H. (2001). An ebit-based model of dynamic capital structure. Journal of Business. 74. 483-512.

[11] Hadlock, C. J. \& James, C. M. (2002). Do Banks Provide Financial Slack?. The Journal of Finance, 57. 1383-1419.

[12] Hamilton, R. T., \& Fox, M. A. (1998). The financing preferences of small firm owners. International Journal of Entrepreneurial Behaviour\& Research. 4(3). 239-248.

[13] Hirshleifer J. (1966). Investment Decision under Uncertainty: Applications of the State-Preference Approach. The Quarterly Journal of Economics. 80(2). 252-277.

[14] Holmes, S., \& Kent, P. (1991). An empirical analysis of the financial structure of small and large Australian manufacturing enterprises. The Journal of Small Business Finance. 1(2). 141-154. 
[15] Ibrahim El-SayedEbaid. (2009). The impact of capital-structure choice on firm performance: empirical evidence from Egypt, The Journal of Risk Finance. 10(5). 477 - 487.

[16] Jensen, M., \& Meckling, W. (1976). Theory of the firm: Managerial behavior, agency costs and ownership structure. Journal of Financial Economics. 3(4). 305-60.

[17] Jensen, M. C. (1986). Agency Costs of Free Cash Flow, Corporate Finance, and Takeovers. American Economic Review. 76(2). 323-329.

[18] Kane, A., Marcus, A. J., \& McDonald, R. L. (1984). How big is the Tax Advantage to Debt? Journal of Finance. 39. 841-53.

[19] Merton H. Miller \& Franco Modigliani. (1961). Dividend Policy, Growth, and the Valuation of Shares. The Journal of Business. 34(4). 411-433.

[20] Modigliani, F. \& Miller, M. (1958). The cost of capital, corporate finance and the theory of investment, American Economic Review, 48. 261-97.

[21] Myers S.C. (1984). The Capital Structure Puzzle. The Journal Of Financ.39(3). 575-592.

[22] Nimalathasan B. \& Brabete V. (2010). Capital Structure and its impact on Profitability: A study of listed Manufacturing companies in Sri Lanka, RevistaTinerilorEconomişti (The Young Economists Journal). 3(5). 7-16.

[23] Nirajini. A., \& Priya, K.B. (2013). Impact of Capital Structure on financial Performance of the listed trading companies in Sri Lanka, International Journal of Scientific and Research Publications. 3(5). $1-9$.
[24] Petersen, M., \& Rajan, R. (1994). The Benefits of Lending Relationships: Evidence from Small Business Data. The Journal of Finance. 49(1), 3-37. doi:10.2307/2329133

[25] Roden, D., \& Lewellen, W. (1995). Corporate Capital Structure Decisions: Evidence from Leveraged Buyouts. Financial Management, 24(2), 76-87. $\quad$ Retrieved from http://www.jstor.org/stable/3665536

[26] Shubita M.F., \& Alsawalhah J.M. (2012), The Relationship between Capital Structure and Profitability, International Journal of Business and Social Science. 3(16). 104-112.

[27] Stiglitz, J. E., (1969). A re-examination of the Modigliani-Miller Theorem. American Economic Review, 59(6). 784- 793.

[28] Strebulaev, A. I. (2007). Do Tests of Capital Structure Theory Mean What They Say?. Journal of Finance, American Finance Association, 62(4). 1747-1787.

[29] Zadeh R.A., Nemati F., Babaei B., \& Narimani. S. (2014) The Relationship between Profitability and Sustainability of the Capital Structure of listed companies in Tehran Stock Exchange, Kuwait Chapter Of Arabian Journal Of Business And Management Review, 3(12a). 249-260.

[30] Zeitun, R., \& Tian, G. G. (2007) Capital structure and corporate performance: evidence from Jordan, Australasian Accounting, Business and Finance Journal. 1(1). 